\title{
Mucopeptide Synthesis by rod Mutants of Bacillus subtilis
}

\author{
By H. J. ROGERS, P. F. THURMAN, C. TAYLOR AND J. N. REEVE* \\ National Institute for Medical Research, Mill Hill, London $\mathrm{NW}_{7}$ I $A A$
}

(Received 28 June 1974)

\begin{abstract}
SUMMARY
Mucopeptide synthesis in rodA and rodB mutants of Bacillus subtilis has been examined by studying the incorporation of $N$-acetyl[I- $\left.{ }^{14} \mathrm{C}\right]$ glucosamine. It has also been examined in a rod $A$ ald mutant by the incorporation of $\mathrm{D}-\left[\mathrm{I}-{ }^{14} \mathrm{C}\right] a$ alanine. In the latter the changes in the ester-linked $\mathrm{D}$-alanine of the teichoic acids was also studied. When the growth temperature for the $\operatorname{rod} A$ mutant is changed from 30 to $45^{\circ} \mathrm{C}$ and the organisms become round, mucopeptide synthesis is increased so that the bacteria finally contain 4 to 5 times as much mucopeptide per unit of dry weight. The change in rate of synthesis is immediate. The change in proportion of ester-linked alanine in the walls is entirely due to dilution of the existing material by additional mucopeptide. This suggests that the large reduction in the proportion of teichoic acid in the walls may similarly be due to dilution by increased mucopeptide. On changing the growth temperature from 45 to $30^{\circ} \mathrm{C}$ the time course for the formation of mucopeptide is complicated, having an initial phase of rapid deceleration and a secondary phase of acceleration to a rate characteristic for the lower temperature. In both the shifts, up and down, the morphological changes accurately reflect the periods of maximum alteration in mucopeptide content. There are no similar changes in $\operatorname{rod} B$ mutants, but a small reduction occurs in the specific activity of the mucopeptide- $N$-acetyl hexosamines, when $N$-acetyl[I- $\left.{ }^{14} \mathrm{C}\right]-$ glucosamine is present in the medium and L-glutamic acid is added to convert the round forms to rods. None of the changes occur in the parent organisms not carrying the rod mutations.
\end{abstract}

\section{INTRODUCTION}

Bacillus subtilis normally grows as a rod of length 2 to $5 \mu \mathrm{m}$ according to the medium and with a diameter of about I $\mu \mathrm{m}$. Its walls, in common with the other bacilli, consist of a relatively simple mucopeptide to which teichoic acids, or under some conditions teichuronic acids, are attached by covalent bonds. A variety of mutants of $B$. subtilis I68 have been described that can grow either as distorted spheres or as normal rod shapes, according to the growth conditions (Rogers, McConnell \& Burdett, 1968, 1970; Boylan \& Mendelson, I969; Cole, Popkin, Boylan \& Mendelson, 1970; Karamata, McConnell \& Rogers, 1972). In the temperature-sensitive mutant (type A) (Boylan \& Mendelson, 1969) the bacteria are rods when grown at $30{ }^{\circ} \mathrm{C}$ but are coccal-shaped at $45{ }^{\circ} \mathrm{C}$. After this morphological transformation has been completed, $80 \%$ of the teichoic acid-phosphorus and $97 \%$ or more of the $N$-acetylglucosamine have been lost from the walls (Boylan, Mendelson, Brooks \& Young, 1972) but the composition of the mucopeptide remains normal. The mutant $B$. subtilis rodro4 type B (Karamata et al. 1972) on the other hand is coccal-shaped when grown in media of low ionic strength but rod-shaped when grown either in media of high ionic strength ( $0.8 \mathrm{M}$-sodium chloride) or in media containing sodium L-glutamate (Rogers \&

* Present address: Max-Planck-Institut für Molekulare Genetik, Abt. Trautner, I Berlin 33 (Dahlem), Ihnestrasse $63-73$, West Germany. 
McConnell, 1970; Karamata et al. 1972). No alteration in the amount of teichoic acidphosphorus occurs during the morphological change but the galactosamine content of the walls is lower in the coccal form (Rogers, McConnell \& Hughes, 1971). It is now known that the walls of the parent B. subtilis 168 contain at least two phosphorus-containing teichoic acid polymers (Duckworth, Archibald \& Baddiley, 1972; Shibaev, Duckworth, Archibald \& Baddiley, I973; Pavlik \& Rogers, 1973), one containing glucose, glycerol and phosphorus, the other $N$-acetylgalactosamine, glucose and phosphorus. Therefore, both mutants can be said to show an alteration in the teichoic acids, but that by the temperaturesensitive type A mutant is very much more dramatic than that by the type B mutants.

In the present paper the biosynthesis of mucopeptide during the morphological change by these two types of rod mutants is examined. A large increase in amount of mucopeptide takes place in type A but not type B mutants, during the change from rod to coccal form. This increase commences immediately, without lag, when the temperature of growth is changed. It would seem reasonable to regard the increased synthesis of mucopeptide as a de-repression phenomenon.

\section{METHODS}

Micro-organisms and growth media. The parent strain was $B$. subtilis metB5 leu-8 ile- $I$ and will be called 172 . Into this strain rodA (tag-I of Boylan et al. 1972) and $\operatorname{rodB}$ genes were introduced by transformation and transduction (Karamata et al. 1972); at the same time the requirement for $\mathrm{L}$-isoleucine or for both $\mathrm{L}$-isoleucine and $\mathrm{L}$-methionine was eliminated. The strain $B$. subtilis met $B 5$ leu-8 rodA will be referred to as strain $\operatorname{rod} A$, whilst $B$. subtilis leu-8 $\operatorname{rod} B$ will be called $\operatorname{rod} B$. Discussion of the nomenclature of these strains is set out in Karamata et al. 1972. Bacillus subtilis ald nic (Berberich, Kaback \& Freese, 1968) was kindly sent to us by Dr E. Freese of the National Institutes of Health, Bethesda, Washington, D.C., U.S.A. Unsuccessful attempts were made to transfer the genes determining the requirement for D-alanine from this strain to $B$. subtilis metB5 leu-8 $\operatorname{rod} A$, but no transformants could be obtained. In consequence, DNA was isolated from $B$. subtilis met $B 5$ leu- $8 \operatorname{rod} A$ and introduced into the D-alanine-requiring strain; at the same time the nicotinic acid requirement was eliminated to give $B$. subtilis ald $\operatorname{rod} A$. This strain will be called rod $A$ ald. Since $B$. subtilis $\mathrm{I} 72$ could no longer be properly regarded as the parent strain for this transformant, a revertant from rodA ald which had lost the RodA phenotype was isolated as B. subtilis ald.

The strains 172 , $\operatorname{rod} A$ and $\operatorname{rod} B$ were grown in the minimal salts-glucose medium of Sargent (1973) and the cultures were shaken to provide aeration. The morphology under the various conditions was frequently checked during the course of the experiments. At the end of each experiment subcultures were made and incubated under the restrictive conditions to ensure that revertants had not been selected under the permissive conditions (i.e. when the mutants appeared as rods and could not be distinguished morphologically from revertants). The D-alanine-requiring strains were grown on casein hydrolysate-yeast extract medium (CHY) (Hughes, I968) supplemented with $40 \mu \mathrm{g}$ D-alanine/ml because their growth in minimal salts media was poor, very slow and required heavy inoculation. Under such conditions a D-alanine requirement for growth could not be demonstrated.

Measurement of growth. The cultures were grown in flasks with side arms. At the required times the cultures were tipped into the side arms and the extinction values at $675 \mathrm{~nm}$ measured on a Unicam 600 spectrophotometer. In separate experiments the extinction values for cultures of all the mutants growing in their various morphological forms were related to measured dry weights. The bacteria were centrifuged from the cultures, washed twice with 
water, and the extinction values of a series of dilutions of the suspensions were measured at $675 \mathrm{~nm}$. Measured volumes from the remainder of the suspensions were then dried to constant weight at $105{ }^{\circ} \mathrm{C}$ and the weights of the residues recorded. Small but significant differences were found according to whether the organisms were coccal- or rod-shaped. Calibration curves for rodA growing in the minimal salts-glucose medium and rodA ald growing in CHY were not identical, for either rod or coccal forms.

Estimation of mucopeptide biosynthesis. The most satisfactory way of measuring mucopeptide synthesis by bacilli would be to study the incorporation of radioactively-labelled 2,6-diaminopimelic acid using an auxotroph requiring both this amino acid and lysine, because under these circumstances only incorporation into mucopeptide and its precursors occurs. Unfortunately, B. subtilis is unable to incorporate 2,6-diaminopimelic acid significantly, and numerous attempts to isolate mutants either requiring it or incorporating it have failed. Two alternative methods were consequently used. In earlier work the incorporation of $\mathrm{N}$-acetyl[I- $\left.{ }^{14} \mathrm{C}\right] \mathrm{glucosamine}$ into the mucopeptide fraction isolated as described below was studied. This method was subsequently confirmed and extended by studying the incorporation of $\mathrm{D}-\left[\mathrm{I}-{ }^{14} \mathrm{C}\right] \mathrm{alanine}$ into the mucopeptide of the $\mathrm{D}$-alanine auxotroph. The general procedure in which $\mathrm{N}$-acetyl[I- $\left.{ }^{14} \mathrm{C}\right]$ glucosamine was used, was to grow the bacteria exponentially with unlabelled $N$-acetylglucosamine $(0.3 \mathrm{mM})$ overnight (IO to 20 generations), to allow induction of the necessary enzymes for transport and/or incorporation of the amino sugar. The next day the cultures, still growing exponentially at a density of about $0 \cdot$ I $\mathrm{mg}$ dry wt/ml, were transferred into the same medium supplemented by $N$-acetyl[I- $\left.{ }^{14} \mathrm{C}\right]-$ glucosamine at a final concentration of $0.3 \mathrm{mM}$ and with a specific activity of $0.2 \mu \mathrm{Ci} / \mu \mathrm{mol}$. These cultures ( $\cdot 1$ to $1 \cdot 0 \mu \mathrm{g} \mathrm{dry} \mathrm{wt} / \mathrm{ml}$ ) were then allowed to grow for 3 to 5 generations, when the conditions of one culture were shifted to obtain the morphological change; two other cultures remained under the conditions at which they had been growing, as controls. Duplicate samples ( $(\mathrm{ml})$ were taken from the cultures into equal volumes of cold $10 \%(\mathrm{w} / \mathrm{v})$ trichloroacetic acid at frequent intervals immediately before the shift and afterwards for as long as bacterial mass increased exponentially.

$\mathrm{D}-\left[\mathrm{I}^{-14} \mathrm{C}\right]$ alanine was used in the same way except that $\mathrm{CHY}$ medium was supplemented by D-[I- $\left.{ }^{14} \mathrm{C}\right]$ alanine $(40 \mu \mathrm{g} / \mathrm{ml} ; 0 . \mathrm{I} 8 \mu \mathrm{Ci} / \mu \mathrm{mol})$. One of the samples taken into trichloroacetic acid was filtered through the glass fibre disc after $24 \mathrm{~h}$, the organisms washed with trichloroacetic acid containing unlabelled D-alanine, and the disc dried. The other sample was used for mucopeptide isolation as described below.

Isolation of mucopeptide. The samples in $5 \%(\mathrm{w} / \mathrm{v})$ trichloroacetic acid were stored overnight at $2{ }^{\circ} \mathrm{C}$. They were then heated to $90{ }^{\circ} \mathrm{C}$ for $20 \mathrm{~min}$ in a water bath, filtered under vacuum through $2.5 \mathrm{~cm}$ glass fibre filters (Whatman $\mathrm{GF} / \mathrm{C}$ ) held on sintered glass discs in Millipore filter holders. The discs were washed with $2 \times \mathrm{I} \mathrm{ml} \mathrm{H}_{2} \mathrm{O}$, and successively with $20 \times 2 \mathrm{ml} 75 \%(\mathrm{v} / \mathrm{v})$ ethanol, $2 \times 10 \mathrm{ml} \mathrm{H}_{2} \mathrm{O}$ and $10 \mathrm{ml} 0 . \mathrm{I} \mathrm{M}-\mathrm{Na}-\mathrm{K}$ phosphate buffer $\mathrm{pH} 8 \cdot 0$. The glass fibre discs were then put into vials containing $2 \mathrm{ml}$ trypsin $(\mathrm{I} \mathrm{mg} / \mathrm{ml})$ dissolved in the same buffer. They were incubated at $35^{\circ} \mathrm{C}$ for 3 to $4 \mathrm{~h}$, and the discs were then removed on to Millipore filter holders (Swinnex-25) containing a dry glass fibre filter. The trypsin solution remaining in the vials was filtered through them and the discs were washed with $2 \times 0.5 \mathrm{ml}$ water before drying for estimation of radioactivity.

Protein synthesis. The 172 strains used required L-leucine. Consequently, L-[2,3-3 $\mathrm{H}] \mathrm{leucine}$ (specific activity $0.14 \mu \mathrm{Ci} / \mu \mathrm{mol}$ ) was included in the minimal salts-glucose medium at a concentration of $0.4 \mu \mathrm{mol} / \mathrm{ml}$. During the preparation of mucopeptide, the residue remaining after extraction with alcohol and with hot and cold trichloroacetic acid was digested with trypsin (see above). A sample ( $\mathrm{r} \cdot 0 \mathrm{ml})$ of the mixed digest and washings was dried on a 
glass fibre disc and counted for tritium to estimate protein biosynthesis. Some organisms incorporate L-leucine into the fatty acids of the phospholipids (Lennarz, 1966). However, with these auxotrophs such incorporation was not sufficient to distort estimates of incorporation into trypsin-digestible protein.

Radioactive counting. The discs from the filter holders and those in the vials were dried overnight at $60^{\circ} \mathrm{C}$, suspended in $5.0 \mathrm{ml}$ toluene containing 2,5-diphenyloxazole $(0.5 \%)$ and I,4-bis-(4-methyl-5-phenyloxazole-2yl) benzene $(0.03 \%)$ and counted for ${ }^{14} \mathrm{C}$ and ${ }^{3} \mathrm{H}$ in a Packard scintillation counter with the appropriate differential settings. More than 2000 counts were collected per sample. For counting liquid samples a dioxane-based scintillation fluid was used (Rogers, 1967).

Estimation of the specific activity of amino sugars. Samples ( $10 \mathrm{ml}$ ) of the cultures containing $\mathrm{N}$-acetyl[I- $\left.{ }^{14} \mathrm{C}\right] \mathrm{glucosamine}$ were taken when the growth had reached about 100 to $200 \mu \mathrm{g} / \mathrm{ml}$, and $10 \%$ (w/v) trichloroacetic acid ( $10 \mathrm{ml}$ ) was added. They were then treated as above for the preparation of mucopeptide up to the stage of drying the filter discs, which were instead transferred to tubes and $\mathrm{I} \mathrm{ml}$ of $4 \mathrm{~N}-\mathrm{HCl}$ added. Condensers were added and the tubes heated at $100{ }^{\circ} \mathrm{C}$ for $4 \mathrm{~h}$. The hydrolysates were filtered, the filter washed with water and the combined filtrate and washings evaporated to dryness in vacuo. The residue was dissolved in $0.5 \mathrm{ml} \mathrm{H} \mathrm{H}_{2} \mathrm{O}$ and $25 \mu \mathrm{l}$ counted. Two columns $(0.75 \times 2 \mathrm{I} \cdot 5 \mathrm{~cm})$ containing Dowex-50 (200 to 400 mesh) previously washed with 21 of 0.1 M-pyridine-acetate buffer, pH $2 \cdot 8$, were eluted with $200 \mathrm{ml}$ of the buffer. Samples $(0 \cdot 2 \mathrm{ml})$ of the dissolved residue were applied to the columns and the flow of buffer continued until 14 to 15 fractions of $5.0 \mathrm{ml}$ had been collected. The buffer was then changed to $0.133 \mathrm{M}$-pyridine-acetate at $\mathrm{pH} 3.85$ and 19 further $5.0 \mathrm{ml}$ fractions collected. The fractions containing radioactivity were pooled and evaporated to dryness in a rotary evaporator, and the residues were dissolved in water, transferred to tubes and evaporated to dryness in vacuo. The final residues were dissolved in 0.2 or $0.5 \mathrm{ml} \mathrm{H} \mathrm{H}_{2} \mathrm{O}$. A control column, to which $0.4 \mu \mathrm{Ci}\left[\mathrm{I}^{14} \mathrm{C}\right]$ glucosamine (specific activity $5 \mu \mathrm{Ci} / \mu \mathrm{mol}), 2 \mu \mathrm{mol}$ galactosamine and $2 \mathrm{mg}$ muramic acid were added, was eluted under exactly the same conditions. Amino sugars and radioactivity were measured in the individual fractions eluted from the columns. Good separation between the amino sugars was obtained.

Incorporation of $\mathrm{D}-\left[\mathrm{I}_{-}{ }^{14} \mathrm{C}\right]$ alanine into teichoic acid. Most teichoic acids examined contain D-alanine attached by an ester linkage to the hydroxyl groups of either the polyol or the sugars. When the mutant rodA ald had been grown in the presence of $\mathrm{D}-\left[\mathrm{I}-{ }^{14} \mathrm{C}\right]$ alanine, over $90 \%$ of the radioactivity appeared in three fractions: (i) the cold trichloroacetic acid $(5 \%)$ extract (for $\mathrm{I} 8 \mathrm{~h}$ at 0 to $4{ }^{\circ} \mathrm{C}$ ); (ii) the mucopeptide; and (iii) the $90{ }^{\circ} \mathrm{C}$ trichloroacetic acid extract. In each fraction the radioactivity was shown by paper chromatography to be present only as alanine. The radioactivity in the first fraction was present mostly as free alanine and was assumed to be pool amino acid. The hot trichloroacetic acid fraction would be expected to contain degraded teichoic acids, and the alanine present was assumed to have been associated with them. If this interpretation is correct, it should be possible to confirm it by preparing the walls from mechanically disrupted organisms and removing the $\mathrm{D}$-alanine from their teichoic acids by treatment with ammonia ( $\mathrm{O} \cdot \mathrm{I} \mathrm{N}$ for $2 \mathrm{~h}$ at room temperature). Allowing for the difficulties of quantitative recoveries of walls, the results from the disrupted organisms agree with those obtained by trichloroacetic acid extraction (Table I). More radioactivity appears in the soluble fraction after disintegration (expt II) and less in the wall fraction, than would have been expected from the trichloroacetic acid extraction. This is presumably due partly to solubilization of wall material during disintegration and partly to possible rupture of the labile ester bond in the teichoic acid. The soluble cytoplasmic material remaining after removing the walls was fractionated on both DEAE and Sephadex 


\section{Table I. Fractionation by trichloroacetic acid extraction and mechanical breakage of $\mathrm{D}-\left[\mathrm{I}-{ }^{14} \mathrm{C}\right]$ alanine incorporated into a culture of rodA ald grown at 30 and $45^{\circ} \mathrm{C}$}

Samples were taken from cultures growing exponentially in CHY medium containing $40 \mu \mathrm{g} / \mathrm{ml}$ $\mathrm{D}-\left[\mathrm{I}-{ }^{14} \mathrm{C}\right]$ alanine (specific activity $0.18 \mu \mathrm{Ci} / \mu \mathrm{mol}$ for $\mathrm{I}$; $0.045 \mu \mathrm{Ci} / \mu \mathrm{mol}$ for II). The results are the means of three successive samples. In I the initial $\mathrm{cpm} / \mathrm{mg}$ bacteria were 2.172 and $5^{.042} \times 10^{4}$, and in II the total radioactivity in the disintegrate was equivalent to $1.43 \times 10^{5}$ and $5.5 \times 10^{5} \mathrm{cpm}$ after growth at 30 and $45{ }^{\circ} \mathrm{C}$, respectively. In I, bacteria were washed and then treated with cold and hot $5 \%(\mathrm{w} / \mathrm{v})$ trichloroacetic acid as described under ' Isolation of mucopeptide'. Trichloroacetic acid was removed from the filtrates by three extractions with an equal volume of diethyl ether, and residual ether removed by a stream of air. All samples were counted by drying onto GFC discs. In II, bacteria were grown and harvested in the same way as for I, but after washing were suspended in one-tenth of the volume of the original culture of $\mathrm{I} \%(\mathrm{w} / \mathrm{v})$ sodium dodecylsulphate to inactivate autolytic enzymes. The suspension was treated for two periods of two min with Ballotini beads in the Braun homogenizer, cooled with liquid $\mathrm{CO}_{2}$ and filtered through sintered glass. The filtrate was centrifuged at $40000 \mathrm{~g}$ for $\mathrm{I} 0 \mathrm{~min}$ at $5{ }^{\circ} \mathrm{C}$ and the supernatant centrifuged at $100000 \mathrm{~g}$ for $30 \mathrm{~min}$ to remove membrane fragments. The final supernatant was called cytoplasmic fractions. The walls were washed repeatedly to remove sodium dodecylsulphate and finally dried from the frozen state.

I. Trichloroacetic acid extraction

Soluble in trichloroacetic acid at $0{ }^{\circ} \mathrm{C}$

Present in the mucopeptide preparation

Soluble in trichloroacetic acid at 90 and not at $0{ }^{\circ} \mathrm{C}$

Radioactivity (\%)*

II. Mechanical breakage

Present in the cytoplasmic fraction (\% of total in

whole organisms)

Soluble material present as free alanine $(\%$ of

cytoplasmic fraction)

Soluble material as 'teichoic acids' (\% cytoplasmic

fraction)

Present in wall preparation ( $\%$ of total in whole organism)

Present in ammonia extract of wall (\% of that in the walls)

\begin{tabular}{|c|c|}
\hline \multicolumn{2}{|c|}{ Growth temperature } \\
\hline $30^{\circ} \mathrm{C}$ & $45^{\circ} \mathrm{C}$ \\
\hline 13 & $3 I$ \\
\hline $4 I$ & 69 \\
\hline 40 & 12 \\
\hline $62 \uparrow$ & $42 \dagger$ \\
\hline 87 & 77 \\
\hline 13 & 23 \\
\hline $27 \ddagger$ & $40 \ddagger$ \\
\hline 54 & I 6 \\
\hline
\end{tabular}

* Results expressed as \% of the total radioactivity in the bacteria.

$\dagger$ Includes the radioactivity in the washings from the walls ( 10 to $20 \%$ of the total).

$\ddagger$ Includes radioactivity (about $10 \%$ of the total) in the lower layers of the wall preparation which may contain some unbroken organisms.

G50 columns and in both cases the excess radioactivity behaved as free amino acid. It was, therefore, provisionally concluded that some of the very labile ester linkages in the walls, particularly from bacteria grown at $30^{\circ} \mathrm{C}$, were hydrolysed during the breakage of the organisms and preparation of the walls. About $10 \%$ of the radioactivity in the cytoplasmic solution from bacteria grown at either temperature behaved as teichoic acid containing both phosphorus and glycerol in approximately equimolar amounts to the D-alanine. In subsequent work, it was assumed that the difference between the amount of $\mathrm{D}-\left[\mathrm{I}-{ }^{14} \mathrm{C}\right] \mathrm{alanine}$ in the residue after extraction at $0{ }^{\circ} \mathrm{C}$ with $5 \%$ trichloroacetic acid and that in the mucopeptide fraction, was an estimate of the ester-linked D-alanine in the wall teichoic acid.

Chemical analysis of the bacteria. Duplicate samples $(20 \mathrm{ml})$ were removed from cultures under the various conditions. An equal volume of $10 \%(\mathrm{w} / \mathrm{v})$ trichloroacetic acid was added to each sample, which was left at $2{ }^{\circ} \mathrm{C}$ overnight and then heated to $90{ }^{\circ} \mathrm{C}$ for $20 \mathrm{~min}$ and centrifuged. The deposit was washed twice with Io $\mathrm{ml}$ amounts of $75 \%$ (v/v) ethanol and 


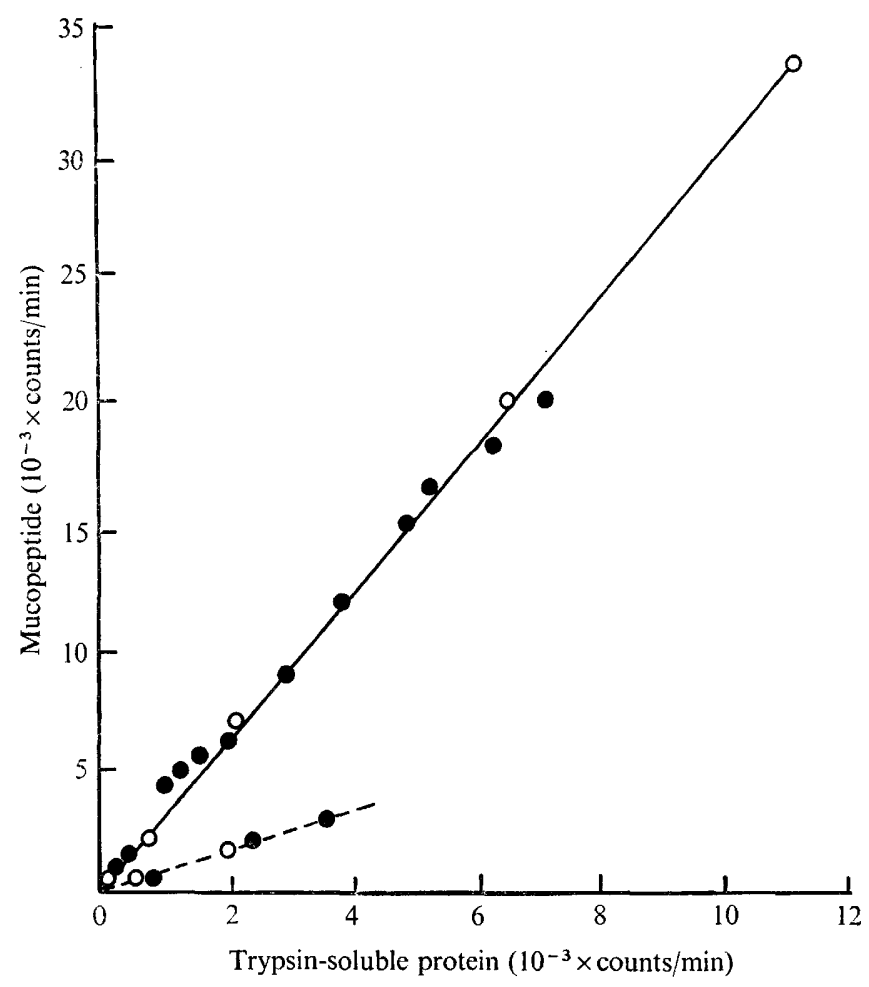

Fig. I. The increase in mucopeptide (measured as $\mathrm{N}$-acetyl[ $\left.\mathrm{I}-{ }^{14} \mathrm{C}\right]$ glucosamine incorporated into the glycan) related to the increase in protein (measured as $\mathbf{L}-\left[2,3^{-3} \mathrm{H}\right]$ leucine incorporated into protein) in exponentially growing cultures of the mutant $\operatorname{rod} A .---$, At $30^{\circ} \mathrm{C} ;--$, switched at time o from 30 to $45^{\circ} \mathrm{C}$; $O$, represent two separate experiments.

suspended in $10 \mathrm{ml} 0 \cdot 2 \mathrm{~N}-\mathrm{NaOH}$. Protein estimations were made on this suspension by the method of Lowry, Rosebrough, Farr \& Randall (195I) using bovine serum albumen as the standard. Another sample $(6.0 \mathrm{ml})$ was adjusted to contain $4 \mathrm{~N}-\mathrm{HCl}$ and heated at $100{ }^{\circ} \mathrm{C}$ for $4 \mathrm{~h}$. The hydrolysate was evaporated to dryness in vacuo and dissolved in $0.5 \mathrm{ml} \mathrm{H}_{2} \mathrm{O}$. Hexosamines were estimated by the method of Levvy \& McAllen (1959). A standard solution of glucosamine- $\mathrm{HCl}$ was taken through the whole procedure and used in the same estimation.

\section{RESULTS}

Effects of changing the temperature of growth of strain rodA and strain rodA ald

Increasing temperature. The radioactivity of the mucopeptide fractions resulting from the incorporation of $\mathrm{N}$-acetyl[ $\left.\mathrm{I}^{14} \mathrm{C}\right] \mathrm{glucosamine}$ increased compared with that of the fraction made soluble by incubation with trypsin and labelled by the $\mathrm{L}-\left[2,3^{-3} \mathrm{H}\right]$ leucine in the medium (Fig. I). Two experiments are included, in which the growth temperature was changed from 30 to $45^{\circ} \mathrm{C}$ at different times after inoculation. The amount of radioactivity due to the mucopeptide fraction increased immediately after the change in growth temperature, with no perceptible lag. The ratio of the radioactivity of the insoluble mucopeptide fraction to that of the trypsin-soluble material was plotted against bacterial dry wt in the exponentially growing cultures (Fig. 2); a rapid increase occurred which lasted for about three generations 


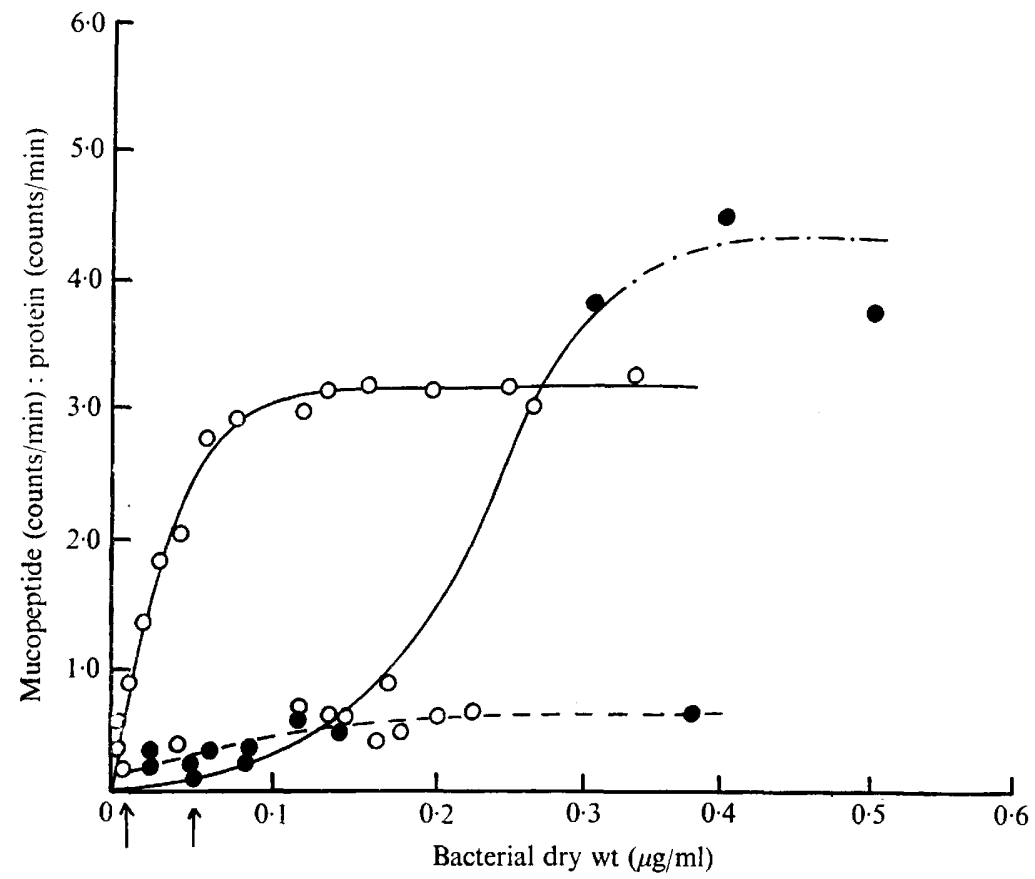

Fig. 2. The increase in the ratio of the amount of mucopeptide to that of protein (measured as in the legend to Fig. I) plotted against bacterial dry wt in exponentially growing cultures of the mutant $\operatorname{rod} A .---$, constantly at $30^{\circ} \mathrm{C}$; $\longrightarrow$, switched from 30 to $45^{\circ} \mathrm{C}$ at the points marked with arrows. Experiment I, O; experiment II,

and then became approximately constant at a ratio that has varied in different experiments between 5 and 8 times greater than that in the cultures kept at $30{ }^{\circ} \mathrm{C}$. Two possibilities exist: either the total amount of mucopeptide per unit of mass increased or the efficiency of incorporation of the precursor $N$-acetyl[ $\left[-{ }^{14} \mathrm{C}\right]$ glucosamine altered. This excludes alteration in the proportion of amino sugars in the mucopeptide, an assumption justified by earlier analyses (Boylan et al. 1972) of the walls of a $\operatorname{rodA}$ mutant grown at 30 and at $45{ }^{\circ} \mathrm{C}$. There were no significant differences in the specific activities of either amino sugar as a result of growing the mutant at 30 or $45^{\circ} \mathrm{C}$ and these activities were similar to that of the precursor, $\mathrm{N}$ acetylglucosamine, in the medium (Table 2). The amount of chemically-estimated amino sugar per unit of protein was 3.7 times as great at the higher growth temperature. Bacteria from cultures which had been maintained at $45^{\circ} \mathrm{C}$ for more than twenty generations were compared with those after only three generations at this temperature, but no significant difference was found by either radioactive or chemical method. The reason for the discrepancy between the ratios (about 5 to 8 from the experiments using $N$-acetyl[ $\left[{ }^{14} \mathrm{C}\right]$ glucosamine compared with 3.7 from the chemical analysis) was not investigated. It was probably due to the relationship between the protein fraction used for radioactive assay and that used for the estimation of total protein by the technique of Lowry et al. (I95I). During growth at $45{ }^{\circ} \mathrm{C}$, the change from rod to coccal shape proceeded throughout the period of increase in mucopeptide content and was complete before the concentration of the polymer became constant at the new higher level indicated from the radioactive studies. The greatest changes seemed to occur towards the end of the period of increase.

Logarithmic plots of incorporation of radioactivity into mucopeptide- and trypsin- 


\section{Table 2. Specific activities of amino sugars and amounts of hexosamine and protein in strain rodA after growth at 30 and $45^{\circ} \mathrm{C}$}

The organisms were grown at the given temperature for at least five generations. The analytical methods were as described in Methods.

Total hexosamine ( $\mu \mathrm{mol} / \mathrm{mg}$ dry wt)

Total protein $(\mu \mathrm{g} / \mathrm{mg}$ dry $\mathrm{wt})$

Specific activity of glucosamine $(\mathrm{cpm} / \mathrm{nmol})$

Specific activity of muramic acid (cpm/nmol)

\begin{tabular}{cc}
$30{ }^{\circ} \mathrm{C}$ & \multicolumn{2}{c}{ rodA } \\
0.04 & 0.16 \\
0.17 & 0.15 \\
$301 \pm 2$ & $280 \pm 9$ \\
$207 \pm 10$ & $220 \pm 26$
\end{tabular}

* Results after growth at $45^{\circ} \mathrm{C}$ were not significantly different.

$172^{*}$
$30{ }^{\circ} \mathrm{C}$
0.12
0.30
$244 \pm 8$
$198 \pm 14$

Table 3. Distribution of radioactivity from $\mathrm{N}$-acetyl $\left[\mathrm{I}-{ }^{14} \mathrm{C}\right]$ glucosamine and $\left[{ }^{3} \mathrm{H}\right]$ leucine in the growth medium during fractionation of rodA

The organisms were grown and fractionated as described in Methods. The protein fraction is that rendered soluble by trypsin acting on bacteria which were previously treated with trichloroacetic acid at $90^{\circ} \mathrm{C}$ for $15 \mathrm{~min}$.

\begin{tabular}{|c|c|c|c|c|c|}
\hline \multirow[b]{2}{*}{$\begin{array}{l}\text { Bacterial } \\
\text { dry wt } \\
(\mu \mathrm{g} / \mathrm{ml})\end{array}$} & \multirow[b]{2}{*}{$\begin{array}{l}\text { Growth } \\
\text { temp. } \\
\left({ }^{\circ} \mathrm{C}\right)\end{array}$} & \multirow{2}{*}{$\begin{array}{c}\text { Mucopeptide } \\
\text { fraction } \\
{ }^{14} \mathrm{C} \\
\left(\mathrm{IO}^{-3} \times \mathrm{cpm}\right)\end{array}$} & \multicolumn{2}{|c|}{ 'Protein' fraction } & \multirow[b]{2}{*}{$\begin{array}{l}\text { Ratio of } \\
\text { mucopeptide }{ }^{14} \mathrm{C} \\
\text { to 'protein' }{ }^{14} \mathrm{C}\end{array}$} \\
\hline & & & ${ }^{14} \mathrm{C}$ & ${ }^{3} \mathrm{H}$ & \\
\hline 44 & 30 & 0.292 & 0.229 & I. 54 & $1 \cdot 27$ \\
\hline $\begin{array}{r}88 \\
125\end{array}$ & & $\begin{array}{l}0.581 \\
I \cdot 22\end{array}$ & $\begin{array}{l}0.410 \\
0.672\end{array}$ & $\begin{array}{l}2.57 \\
3 \cdot 46\end{array}$ & $\begin{array}{l}1.4 \mathrm{I} \\
\mathrm{I} \cdot 8 \mathrm{I}\end{array}$ \\
\hline $\begin{array}{r}78 \\
240 \\
320\end{array}$ & 45 & $\begin{array}{l}5.17 \\
19 \cdot 8 \\
30 \cdot 7\end{array}$ & $\begin{array}{l}0.694 \\
2.88 \\
3.88\end{array}$ & $\begin{array}{r}3.21 \\
13.3 \\
\mathrm{I} 8.2\end{array}$ & $\begin{array}{l}7 \cdot 45 \\
6 \cdot 87 \\
7 \cdot 9\end{array}$ \\
\hline
\end{tabular}

soluble fractions against time showed an initially steeper slope for the former after shifting to $45^{\circ} \mathrm{C}$ than for the increase in mass. The increase in the tritium-labelled material made soluble by trypsin and assumed to derive from protein was parallel to that for mass. This result is to be expected if all or a high proportion of the radioactivity in the trypsin-soluble fraction is present in peptides from hydrolysed protein. Only a small alteration in the proportion of protein per unit mass had occurred (Table 2).

The disadvantages of the use of $N$-acetyl[ $\left[-{ }^{14} \mathrm{C}\right]$ glucosamine to study mucopeptide synthesis are emphasized in Table 3. In rich media (e.g. acid hydrolysed casein-glucose) not more than $10 \%$ of the total radioactivity from $N$-acetylglucosamine incorporated into the cells is found in the fraction dissolved by trypsin (H. M. Pooley, personal communication) but in minimal salts-glucose media such as are used here the proportion is much higher and varies during growth (Table 3). In view of these facts and the discrepancy between the chemical analyses and the radioactive incorporations it was desirable to confirm the kinetic results by studying the incorporation of $\mathrm{D}-\left[\mathrm{I}-{ }^{14} \mathrm{C}\right]$ alanine into the mucopeptide of the $\mathrm{D}$ alanine-requiring strain. This method also allows the behaviour of the ester-linked D-alanine of the teichoic acid to be examined as well as the amino acid in the mucopeptide. The effect of raising the growth temperature upon the synthesis of mucopeptide measured in this way (Fig. 3) is very similar to that recorded in Fig. 2. Due to the use of complex media and the absence of a requirement by the mutant for amino acids other than D-alanine, protein synthesis could not be measured satisfactorily by incorporation of a labelled amino acid. 


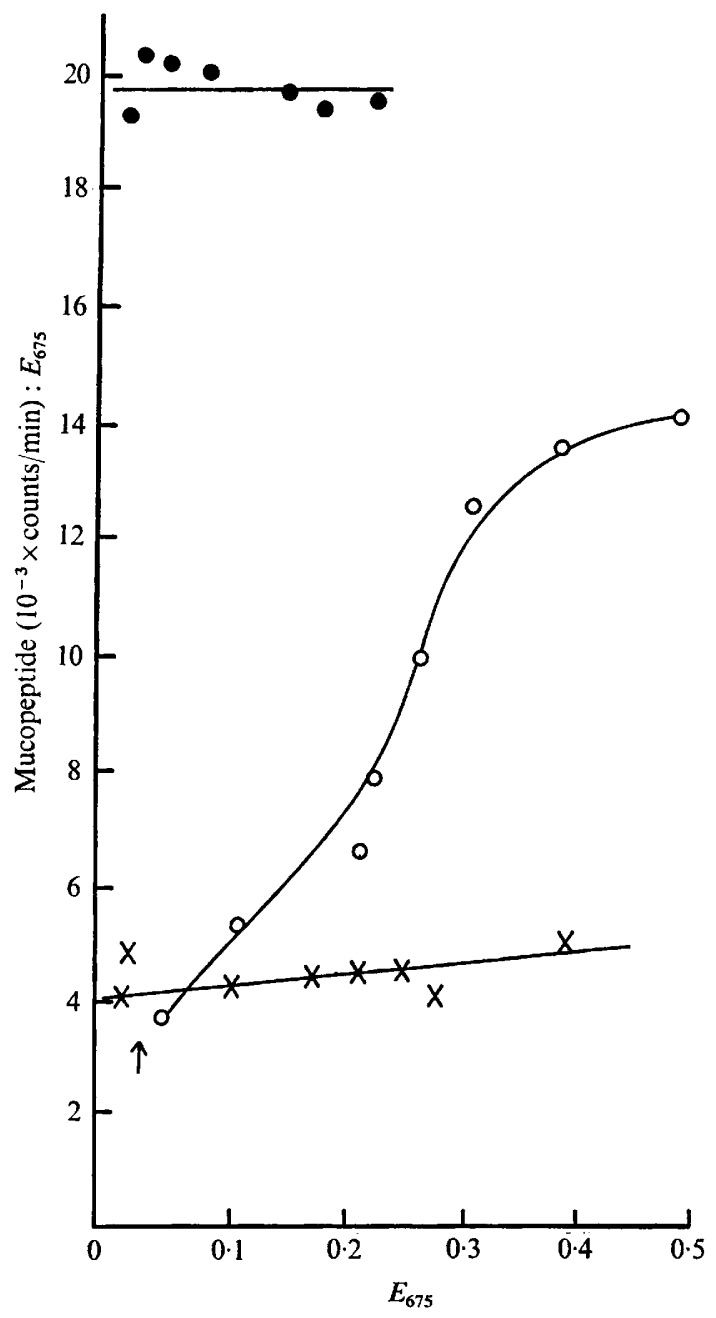

Fig. 3. The increase in the ratio amount of mucopeptide:extinction in exponentially growing cultures of the mutant rod $A$ ald. The mucopeptide was measured by the radioactivity incorporated from $\mathrm{D}-\left[\mathrm{I}^{-14} \mathrm{C}\right]$ alanine. $-\times-$ Kept at $30^{\circ} \mathrm{C} ;-\mathrm{O}-$, kept at $45^{\circ} \mathrm{C}$; $-\bigcirc-$, switched from 30 to $45^{\circ} \mathrm{C}$ at the point marked with an arrow.

However, the increase in the ratio of the radioactivity of the mucopeptide to the dry weight of the organisms after shifting the growth temperature shows that there is a large increase in the proportion of mucopeptide in the cell that starts immediately after the shift and is closely correlated with the morphological change of the bacteria. Moreover, the ratio of the radioactivity of the mucopeptide fraction from bacteria grown at $45^{\circ} \mathrm{C}$ to that in this fraction from cultures at $30^{\circ} \mathrm{C}$ is very similar to that determined by chemical estimation of hexosamine in the two fractions (Table 2).

Decreasing temperature. It is unlikely that when the growth temperature is switched from 45 to $30^{\circ} \mathrm{C}$ the larger amount of mucopeptide present in the coccal-shaped bacteria is simply diluted out until the concn/unit mass reaches the value characteristic of growth at the lower temperature. The logarithm of the amount of $\mathrm{N}$-acetyl[ $\left.\mathrm{I}-{ }^{14} \mathrm{C}\right] \mathrm{glucosamine}$ incorporated into the mucopeptide fraction plotted against time (Fig. 4) showed that the exponential 


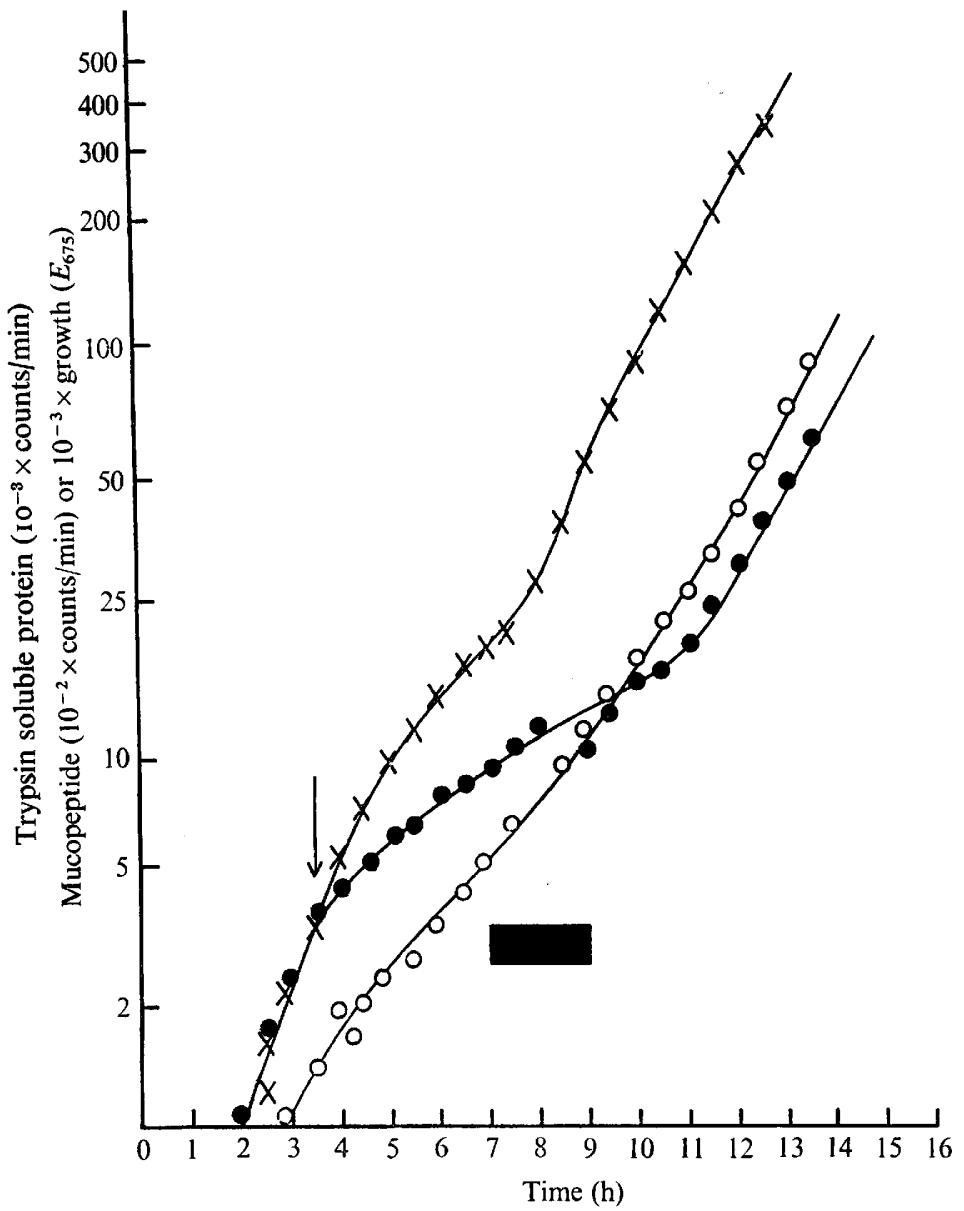

Fig. 4. The effect of switching $(\downarrow)$ the temperature of growth from 45 to $30{ }^{\circ} \mathrm{C}$ on mucopeptide and protein synthesis and on growth of the mutant $\operatorname{rod} A .-\times-, E_{675} ;-O-$, protein; - mucopeptide. Mucopeptide and protein were measured as described in the legend to Fig. I. The horizontal bar marks the region of morphological change.

rate of incorporation was reduced to about one-third of that characteristic of growth in mass at $45{ }^{\circ} \mathrm{C}$. Mucopeptide synthesis then decelerated still further until $5 \mathrm{~h}$ after the shift, when it almost stopped. It then re-accelerated to the exponential rate characteristic of $30{ }^{\circ} \mathrm{C}$. Mass increase also showed a hesitation, but $3.5 \mathrm{~h}$ after the shift. The exponential increase in the radioactivity in the trypsin-soluble fraction decelerated almost immediately after the shift from 45 to $30^{\circ} \mathrm{C}$ and stayed at a constant exponential rate. The result of these various changes is that the ratio of the radioactivity in the mucopeptide fraction to that in the trypsin-soluble fraction material, shows a deceptively simple exponential decline (Fig. 5). In view of the complexities of the changes shown in Fig. 4 it seems that this exponential fall does not mean that the fall in the amount of mucopeptide is achieved by an abrupt reduction in its relative rate of synthesis, followed by dilution of the excess present. The slope of the line (Fig. 5) is equivalent to a $t_{1}$ of 150 min compared with a doubling time for the bacterial mass of $66 \mathrm{~min}$, again showing that simple dilution of the excess mucopeptide is not the only operative factor. The morphological changes, as seen by the phase-contrast light microscope, occur principally during the period when synthesis of mucopeptide is rapidly decelerating. 


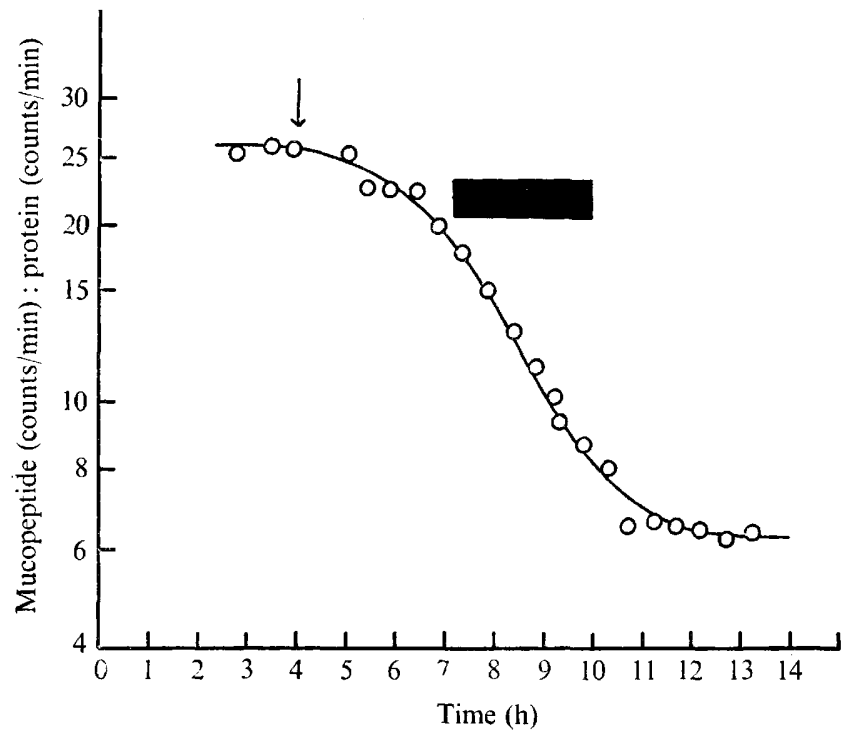

Fig. 5. Change in the ratio amount of mucopeptide: protein in exponentially growing cultures of $\operatorname{rod} A$ switched from growing at 45 to $30^{\circ} \mathrm{C}$ (arrow). The bar marks the region of morphological change.

Effects of altering growth temperature upon incorporation of $\mathrm{D}-\left[\mathrm{I}^{14} \mathrm{C}\right]$ alanine into teichoic acid. The amounts of D-alanine incorporated into mucopeptide and teichoic acid, calculated per unit bacterial mass, changed little with growth temperature (Table 4), whereas the amount of alanine in the mucopeptide fraction was increased about five times by growth at $45^{\circ} \mathrm{C}$. Thus the change in the ester-linked alanine content of the walls (measured per unit mass of wall, not per bacterium; i.e. $54 \%$ to $16 \%$, see Table I) can be accounted for by dilution by an increased formation of mucopeptide rather than by a decreased formation of teichoic acid.

\section{Growth of rodB with different glutamate concentrations}

Previous results (Rogers et al. 197I) have shown no significant differences between the mucopeptide content per unit mass of the coccal and rod forms of rodB grown in liquid cultures. In this earlier work, 2,6-diaminopimelic acid was used as a chemical marker for mucopeptide estimation. The molar proportions of the mucopeptide constituents were likewise similar in wall preparations from the two morphological forms. It seemed unlikely that the transformant rodB104, produced from the strain rod-4 originally studied, would behave like $\operatorname{rod} A$ and show a great increase in mucopeptide during the change from a rod to a coccus that occurs when it is deprived of glutamate. Nevertheless, incorporation of $\mathrm{N}$-acetyl[I- $\left.{ }^{14} \mathrm{C}\right]$ glucosamine into mucopeptide was measured in the presence and absence of sodium-L-glutamate $(0.3 \%)$. When sodium-L-glutamate was added to exponentially growing cultures of $\operatorname{rod} B$, a somewhat reduced incorporation of radioactivity in the presence of the amino acid was found. This did not correspond to a decrease in the cellular content of amino sugars (Table 5). There appeared, therefore, to be no evidence for an alteration of the mucopeptide content of the bacteria with the change in morphological form. This confirms our earlier results (Rogers et al. I97I). Specific activity determinations on the amino sugars in the mucopeptides showed that they were somewhat depressed by the presence of sodiumL-glutamate in the growth medium (Table 5). This reduction precisely accounted for the 


\section{Table 4. Incorporation of $\mathrm{D}$-alanine into growing cultures of rodA ald}

The organisms were grown and fractionated as described in Methods. The 'teichoic' acid fraction refers to the fraction of the D-alanine that was soluble in trichloroacetic acid within 20 min at $90{ }^{\circ} \mathrm{C}$. The results were calculated from the radioactivity; the initial specific activity of the D-alanine in the medium was $9.9 \times 10^{4} \mathrm{cpm} / \mu \mathrm{mol}$. The counting efficiency of ${ }^{14} \mathrm{C}$ under our conditions was $78.4 \%$. The results shown for each experiment represent the average of ten separate measurements.

\begin{tabular}{lccc} 
& & \multicolumn{1}{c}{$\begin{array}{c}\text { D-alanine } \\
(\mu \mathrm{mol} / \mathrm{mg} \text { dry wt })\end{array}$} \\
'Teichoic' acid fraction & Experiment & $0.10 \pm 0.02$ & $0.13 \pm 0.02$ \\
& I & $0.29 \pm 0.03$ & $0.21 \pm 0.02$ \\
Mucopeptide fraction & III & $0.13 \pm 0.02$ & $0.13 \pm 0.02$ \\
& I & $0.09 \pm 0.02$ & $0.41 \pm 0.01$ \\
& II & $0.1 \mathrm{C} \pm 0.01$ & $0.61 \pm 0.02$ \\
& III & $0.10 \pm 0.01$ & $0.50 \pm 0.02$
\end{tabular}

Table 5. The effect of $0.3 \%$ sodium-L-glutamate (SG) on the amounts and specific activities of the amino sugars and the amounts of protein in strain rodB and its parent 172

The conditions for growth and mucopeptide preparation were as described in Methods. For specific activity determinations the bacteria were harvested at an extinction value equivalent to $100 \mu \mathrm{g} / \mathrm{ml}$. The initial specific activity of the $N$-acetylglucosamine in the growth medium was $264 \mathrm{cpm} / \mathrm{nmol}$.

Total hexosamine $(\mu \mathrm{mol} / \mathrm{mg}$ dry wt)

Total protein $(\mu \mathrm{g} / \mathrm{ml}$ dry wt)

Specific activity of glucosamine (cpm/nmol)

Specific activity of muramic acid (cpm/nmol)

$\begin{array}{cc}\overbrace{\text { No SG }} & \text { SG } \\ 0.14 & 0.14 \\ 0.35 & 0.38 \\ 234 \pm 2 & 197 \pm 0 \\ 242 \pm 12 & 188 \pm 8\end{array}$

$\begin{array}{cc}\overbrace{\text { No SG }} & \text { SG } \\ 0.12 & 0.12 \\ 0.30 & 0.30 \\ 244 \pm 8 & 222 \pm 17 \\ 198 \pm 14 & 184 \pm 8\end{array}$

reduction of radioactivity incorporated into the mucopeptide fraction. The protein content of the bacteria per unit of mass was also unaffected by the presence or absence of $0.3 \%$ sodium-L-glutamate in the minimal salts-glucose medium. Unfortunately, no D-alanine auxotroph of $\operatorname{rodB}$ is available to allow confirmation of these results.

\section{The effects of different growth conditions on the parent micro-organisms}

The parent $B$. subtilis 172 grows at $30{ }^{\circ} \mathrm{C}$ in the presence and absence of $0.3 \%$ sodiumL-glutamate and in the absence of the amino acid at $45^{\circ} \mathrm{C}$ as a normal-shaped rod. The incorporation of radioactivity from $N$-acetyl[ $\left[{ }^{-14} \mathrm{C}\right]$ glucosamine was the same at $45{ }^{\circ} \mathrm{C}$ as it was at $30^{\circ} \mathrm{C}$. When the ratio of incorporation into the mucopeptide fraction to that into the trypsin-soluble fraction was plotted against mass of growth, a small, barely significant rise occurred both in the bacteria growing at $30{ }^{\circ} \mathrm{C}$ and in those shifted to $45^{\circ} \mathrm{C}$. The stable ratio was somewhat higher for the culture remaining at $30^{\circ} \mathrm{C}$ than in that shifted to $45^{\circ} \mathrm{C}$. This reflected a slight apparent depression of incorporation of $\mathrm{L}-\left[2,3^{-3} \mathrm{H}\right]$ leucine into protein or an increased protein content at a growth temperature of $45^{\circ} \mathrm{C}$. The presence of sodiumL-glutamate in the growth medium has no significant effect either on the specific activities of the amino sugars or on the analytical composition of the bacteria (Table 5). The revertant of the strain $\operatorname{rod} A$ ald also showed only small differences in the ratio of the radioactivity incorporated from $\mathrm{D}-\left[\mathrm{I}^{14} \mathrm{C}\right]$ alanine into the mucopeptide to the dry weight according to whether growth was at $30^{\circ} \mathrm{C}, 45^{\circ} \mathrm{C}$ or variable. 
Table 6. Summary of properties of rod and other mutants showing a rod-coccal morphological change

\begin{tabular}{|c|c|c|c|c|c|}
\hline \multirow[b]{2}{*}{ Micro-organism } & \multirow[b]{2}{*}{ Type } & \multirow{2}{*}{$\begin{array}{l}\text { Suggested map } \\
\text { position }\end{array}$} & \multicolumn{2}{|c|}{ Growth conditions for } & \multirow[b]{2}{*}{ Reference } \\
\hline & & & Cocci & Rods & \\
\hline $\begin{array}{l}\text { Bacillus } \\
\text { subtilis }\end{array}$ & A & tag-I rodA $f a C$ & $45^{\circ} \mathrm{C}$ & $30^{\circ} \mathrm{C}$ & $\begin{array}{l}\text { Boylan \& Mendelson } \\
(1969,1970)\end{array}$ \\
\hline B. subtilis & B & leu-8 rodB phe $A \mathrm{I} 2$ & $\begin{array}{l}\text { Low salt } \\
\text { Low sodium } \\
\text { L-glutamate }\end{array}$ & $\begin{array}{l}\text { High salt and } \\
\text { low sodium } \\
\text { L-glutamate or } \\
\text { high sodium } \\
\text { L-glutamate }\end{array}$ & $\begin{array}{l}\text { Rogers et al. }(1968,1970) \\
\text { Karamata et al. }(1972)\end{array}$ \\
\hline B. subtilis & C & his $A$ rodC & Low salt & High salt & Karamata et al. (1972) \\
\hline $\begin{array}{l}\text { B. licheni- } \\
\text { formis } 6346\end{array}$ & 一 & - & Low salt & High salt & Rogers et al. (1968, 1970) \\
\hline $\begin{array}{l}\text { B. licheni- } \\
\text { formis } 6346\end{array}$ & PGM & - & $\begin{array}{l}\text { Phosphate } \\
\text { limitation }\end{array}$ & Normal media & Forsberg et al. (1973) \\
\hline Escherichia coli & - & - & Not conditional & 一 & Adler et al. (1968) \\
\hline E. coli & - & near str $A$ & Not conditional & - & Normak (1969) \\
\hline E. coli & - & near $g a l$ & $42^{\circ} \mathrm{C}$ & $30^{\circ} \mathrm{C}$ & Henning et al. (1972) \\
\hline E. coli & $\operatorname{rod} A$ & near lip & $37^{\circ} \mathrm{C}$ & $25^{\circ} \mathrm{C}$ & Matsuzawa et al. (1973) \\
\hline $\begin{array}{l}\text { Agrobacterium } \\
\text { tumefaciens }\end{array}$ & - & - & Not conditional & - & Fujiwara \& Fukui (1972) \\
\hline
\end{tabular}

\section{DISCUSSION}

Mutants that undergo the rod-coccal morphological change, have now been described in Bacillus subtilis (Rogers et al. 1968, 1970; Boylan \& Mendelson, 1969) in Escherichia coli (Adler, Terry \& Hardigree, I968; Normak, I969; Henning, Rehn, Braun, Hohn \& Schwarz, 1972; Matsuzawa, Hayakawa, Sato \& Imahari, 1973) in B. licheniformis (Rogers et al. 1968, I970; Forsberg, Wyrick, Ward \& Rogers, 1973; Forsberg \& Rogers, 1974) and in Agrobacterium tumefaciens (Fujiwara \& Fukui, 1972). These mutants are listed in Table 6. The genetic lesions in $B$. subtilis causing the $\operatorname{rod} A$ and $\operatorname{rod} B$ mutations map in two different regions of the chromosome (Boylan et al. 1972; Karamata et al. 1972) and require different conditions to change their morphology. In $E$. coli only one of the mutants is conditional, but again at least two different regions of the chromosome are involved in the various rod mutants of this species. In $B$. licheniformis nothing is known about the map positions of the genes, but different physiological lesions seem likely to be involved in the phenotypes. Among the $B$. subtilis mutants it is already known (Cole et al. 1970; Boylan et al. 1972) that the temperature-sensitive mutant, called here $\operatorname{rod} A$, has a greatly reduced proportion of teichoic acids in its wall when grown at $45^{\circ} \mathrm{C}$ as a coccus, whereas rodB grown as a coccus in minimal salts media with low concentrations of glutamate and salt has normal amounts of organic phosphorus in the wall but a reduced amount of $\mathrm{N}$-acetylglucosamine. No deficiency of the enzymes necessary to make glycosylated polyglycerol phosphate were detected in the temperature-sensitive mutant (Boylan et al. 1972) grown at $45^{\circ} \mathrm{C}$ despite the deficiency of teichoic acid in its walls. The enzymes necessary for making the teichoic acid that consists of $N$-acetylgalactosamine, phosphorus and glucose now known to be present in the walls of B. subtilis $\mathrm{I} 68$ (Duckworth et al. 1972) were not sought, and nor were those for making other possible polymers containing galactosamine and glucose and phosphorus which may be present (Duckworth et al. 1972; Pavlik \& Rogers, I973; unpublished observa- 
tions). The amount of mucopeptide per unit weight of $\operatorname{rodA}$ grown at $45^{\circ} \mathrm{C}$ is 4 times that at $30^{\circ} \mathrm{C}$ by chemical estimation, but about 5 times greater by isotope incorporation methods. In order to change the teichoic acid-alanine content of the walls from 54 to $16 \%$, the mucopeptide content would have to increase about 6 times. Thus most of the reduction in the proportion of teichoic acid in the walls could be accounted for by the increased amount of mucopeptide, with no change in teichoic acid synthesis. However, so far only the ester D-alanine in the teichoic acid has been measured, and therefore no account can be taken of possible differences in degrees of substitution of the teichoic acid by Dalanine. The teichoic acid molecules in the walls also contain phosphate, glycerol, glucose and $N$-acetylgalactosamine, and the present results should be accepted as suggestive rather than definitive. A failure to shut off teichoic acid synthesis as completely as had been supposed from analysis of the walls would, however, be consistent with the continued presence in the mutant grown at $45^{\circ} \mathrm{C}$ of the key enzymes necessary for teichoic acid synthesis (Boylan et al. 1972).

The importance of having sufficient negatively-charged polymers linked to the mucopeptide to obtain the proper replication of the usual rod-shape of bacilli is illustrated both by the behaviour of the rodA mutants and that of the mutants of B. licheniformis or B. subtilis lacking phosphoglucomutase when subjected to growth limitation by inorganic phosphate (Forsberg et al. 1973). These mutants then form walls without significant amounts of negative polymers attached and are also round shaped. It seems to be irrelevant to the organism whether the lack of negative macroanions is due to a failure of their formation or to dilution by increased formation of mucopeptide.

It would be desirable to relate the molecular changes both to quantitative aspects of the morphology and to the process of cell division. The shape and mode of growth of these mutants makes both of these problems complicated. The so-called round form when examined in detail (Rogers et al. 1970) are an extremely irregularly-shaped sub-divided group of organisms, such that viable, or electronically made, counts on cultures would be of little significance and it is difficult to know which parameters to measure in order to quantify their shape. One possible approach to enumeration of the bacteria is to convert the culture to protoplasts and then to count these electronically (M. M. McConnell \& H. J. Rogers, unpublished work). This method, however, requires careful study before it can be applied to the type of experiments described in this paper.

Present evidence would suggest that there are two ways of arriving at the round morphology, since the $\operatorname{rod} B$ mutants show neither gross loss of steichoic acid nor increased formation of mucopeptide. At best the present results have only demonstrated a small difference in the specific activity of the amino sugars of the mucopeptide in the presence of L-glutamate. This may well be a secondary effect resulting from the main lesion, which unpublished results suggest is of a quite different nature.

\section{REFERENCES}

Adler, H. I., Terry, C. E. \& Hardigree, A. A. (1968). Giant cells of Escherichia coli. Journal of Bacteriology 95, I39-I 42.

Berberich, R., Kaback, M. \& FreEse, K. E. (1968). D-amino acids as inducers of L-alanine dehydrogenase in Bacillus subtilis. Journal of Biological Chemistry 243, 1006-101 I.

Boylan, R. J. \& MENDELSON, N. H. (1969). Initial characterization of a temperature sensitive Rod $^{-}$mutant of Bacillus subtilis. Journal of Bacteriology 100, 1316-1321.

Boylan, R. J., Mendelson, N. H., Brooks, D. \& Young, F. E. (1972). Regulation of the bacterial cell wall: analysis of a mutant of Bacillus subtilis defective in biosynthesis of teichoic acid. Journal of Bacteriology 110, 281-290. 
Cole, R. M., Popkin, T. J., Boylan, R. J. \& Mendelson, N. H. (1970). Uitrastructure of a temperaturesensitive Rod $^{-}$mutant of Bacillus subtilis. Journal of Bacteriology 103, 793-810.

Duckworth, M., ARChibald, A. R. \& Baddiley, J. (1972). The location of $N$-acetylgalactosamine in the walls of Bacillus subtilis i68. Biochemical Journal 130, 691-696.

Forsberg, C. W. \& Rogers, H. J. (I974). Characterization of Bacillus licheniformis 6346 mutants which have altered lytic enzyme activities. Journal of Bacteriology I18, 358-368.

ForsBerg, C. W., Wyrick, P. B., WARD, J. B. \& Rogers, H. J. (I973). Effect of phosphate limitation on the morphology and wall composition of Bacillus licheniformis and its phosphoglucomutase-deficient mutants. Journal of Bacteriology $1 \mathbf{1 3}_{3}, 969-984$.

FuJiWARA, T. \& FukUI, S. (1972). Isolation of morphological mutants of Agrobacterium tumefaciens. Journal of Bacteriology I10, 743-746.

Henning, U., Rehn, K. Braun, V., Hohn, B. \& Schwartz, U. (1972). Cell envelope and shape of Escherichia coli K I 2. Properties of a temperature-sensitive rod mutant. European Journal of Biochemistry 26, 570-586.

HUGHES, R. C. (1968). The cell wall of Bacillus licheniformis NCTC6346: isolation of low-molecular-weight fragments from the soluble mucopeptide. Biochemical Journal ro6, 49-59.

Karamata, D., McConnell, M. M. \& Rogers, H. J. (I972). Mapping of rod mutants of Bacillus subtilis. Journal of Bacteriology III, 73-79.

Lennarz, W. J. (1966). Advances in Lipid Research, vol. 4, pp. 175-225. Edited by R. Paoletti and D. Kritchevsky. New York and London: Academic Press.

Levvy, G. A. \& McAllen, H. (1959). The $N$-acetylation and estimation of hexosamines. Biochemical Journal 73, I27-I 32.

Lowry, O. H., Rosebrough, N. J., Farr, A. Z. \& Randall, R. J. (195I). Protein measurement with the Folin reagent. Journal of Biological Chemistry 193, 265-275.

Matsuzawa, H., Hayakawa, K., Sato, T. \& Imahari, K. (1973). Characterization and genetic analysis of a mutant of Escherichia coli KI 2 with rounded morphology. Journal of Bacteriology II5, 436-442.

NormaK, S. (1969). Mutation in Escherichia coli $\mathrm{KI} 2$ mediating sphere-like envelopes and changed tolerance to ultraviolet irradiation and some antibiotics. Journal of Bacteriology 98, I 274-1 277.

Pavlik, J. G. \& Rogers, H. J. (I973). Selective extraction of polymers from cell walls of Gram-positive bacteria. Biochemical Journal 131, 619-621.

ROGERS, H. J. (1967). The inhibition of mucopeptide synthesis by benzylpenicillin in relation to irreversible fixation of the antibiotic by staphylococcus. Biochemical Journal ro3, 90-102.

Rogers, H. J. \& MCConnell, M. M. (1970). The role of L-glutamine in the phenotypic change of a rod mutant derived from Bacillus subtilis I68. Journal of General Microbiology 6r, 173-18I.

Rogers, H. J., MCConNell, M. M. \& BURDeTt, I. D. J. (1968). Cell wall or membrane mutants of Bacillus subtilis and Bacillus licheniformis with grossly deformed morphology. Nature, London 219, 285288.

Rogers, H. J., McConnell, M. M. \& BurdetT, I. D. J. (1970). The isolation and characterization of mutants of Bacillus subtilis and Bacillus licheniformis with disturbed morphology and cell division. Journal of General Microbiology 6r, 155-I7I.

Rogers, H. J., MCConnell, M. M. \& Hughes, R. C. (197I). The chemistry of the cell walls of rod mutants of Bacillus subtilis. Journal of General Microbiology 66, 297-308.

SARGENT, M. G. (1973). Synchronous cultures of Bacillus subtilis obtained by filtration with glass fibre filters. Journal of Bacteriology II6, 736-740.

Shibaey, U. N., Duckworth, M., Archibald, A. R. \& Baddiley, J. (1973). The structure of a polymer containing galactosamine from walls of Bacillus subtilis. Biochemical Journal 135, 383-384. 